\title{
INSM2 Gene
}

National Cancer Institute

\section{Source}

National Cancer Institute. INSM2 Gene. NCI Thesaurus. Code C148303.

This gene may play a role in the repression of genes involved in cell growth. 